\title{
Corrigendum
}

\section{Glucose starvation induces cell death in K-ras-transformed cells by interfering with the hexosamine biosynthesis pathway and activating the unfolded protein response}

R Palorini, FP Cammarata, C Balestrieri, A Monestiroli, M Vasso, C Gelfi, L Alberghina and F Chiaradonna

Cell Death and Disease (2013) 4, e910; doi:10.1038/cddis.2013.390; published online 7 November 2013

Correction to: Cell Death and Disease (2013) 4, e732; doi:10.1038/cddis.2013.257; published online 18 July 2013

Since the publication of this article, the authors have noticed that Francesco Paolo Cammarata's name was incorrect. The correct author list is shown above. The corrected article appears online together with this corrigendum.
The authors would like to apologize for any inconvenience. 